\title{
Crime Prevention on Farms: Experiences from Victoria, Australia
}

\author{
Alistair Harkness \\ Lecturer, School of Arts, Humanities and Social Sciences \\ Gippsland Camus \\ Federation University \\ Northways Road \\ Churchill, Victoria, Australia 3842 \\ Contact Author - Alistair Harkness; alistair.harkness@federation.edu.au, +613 51226760
}

\begin{abstract}
Whilst rural offending has hitherto been largely overlooked, the canon of scholarly examination of rural crime - including farm crime literature - is slowly growing. In addition to bearing financial costs for farming communities, rural crime bears significant social impacts. Implementation of crime prevention tactics and techniques is, therefore, essential to reducing farmer victimisation. Focussing on property theft from farms in Victoria, Australia, this article draws upon interviews with rural police members and survey data obtained from farmers, and considers the opportunities presented to offenders - often unwittingly by farmers themselves. It considers the situational crime prevention categories of increasing effort, increasing risk and reducing rewards - although developed for urban environments -for farmers and police in rural areas; and argues that improved capable guardianship on farms through human and electronic means, although difficult to achieve, can address farm victimisation and offending rates.
\end{abstract}

Keywords: situational crime prevention; farm crime; capable guardians, crime reporting; Australia 


\section{Introduction}

Rural crime is multi-faceted and occurs both on private property (notably on farms) and in public spaces within townships and hamlets. No universal definition of 'rural' exists (Flora and Flora 2008, 7-8); nor are there unanimous definitions for rural crime or indeed for farm crime specifically (Anderson and McCall 2005, vii; Carcach 2000, 2). Nevertheless, it is generally understood that farm crime consists of property offences which occur on farms (such as theft, vandalism, arson and illegal hunting) and environmental offences (such as illegal dumping and drug production) (Barclay and Donnermeyer 2007, 57). Interpersonal violence is also present in farming communities (see, for example, George and Harris 2014).

This article assesses issues pertaining specifically to property theft from farms, with a primary focus on the applicability of situational crime prevention responses (SCP) in rural Victoria in south-east Australia. In seeking to expand understanding of thefts from farms, this framework is premised on the truism that 'prevention is better than cure'; and seeks to identify initiatives for prevention and control of property crime, and the improvement of service delivery to confront an increasingly important aspect of crime and crime control. In 2011, 157,000 farmers operated in Australia; and agricultural output as a proportion of the economy in Australia was "among the highest in the OECD" (Organisation for Economic Co-operation and Development) (ABS 2012). Australian farms contribute two percent of the country's Gross Domestic Product; and the gross value of farm production in 2012-13 was \$48 billion (NFF,2014, 6). Given the role farming plays in the Australian national economy, and the existence of similar challenges for farmers and police regardless of state and territory borders, experiences from Victoria could well serve as a guide for other jurisdictions.

A significant proportion of farms in Australia experience crime (McCall 2003; Barclay et al 2001; Carcach 2002) and, indeed, farm victimisation can impact "the entire rural community and the wider agricultural industry" (McCall 2003, 1). Anderson and McCall (2005, ix) note that in addition to direct financial costs to the Australian economy, productive farmers leave the sector as a consequence of victimisation. Barclay and Donnermeyer (2007, 60-61) observe that the many societal impacts of farm crime include direct financial costs to individual farmers. In addition to losses sustained as a consequence of theft, lost work time and impact on annual income, higher insurance premiums, and for livestock theft the loss of breeding stock. Other impacts include a loss of cohesiveness within a local community; and export trade implications (by, for instance, the introduction of unhealthy stock into the marketing and process chain). Worryingly, research also indicates that repeat victimisation against farmers is high (McCall and Home 2003, 1).

Preventing farm crime, therefore, is important. Effective crime prevention can reduce lost output, harm and intangible costs: as noted by the United Nations $(2004,1)$, “... in the matters of 
justice and the rule of law, an ounce of prevention is worth significantly more than a pound of cure... prevention is the first imperative of justice". It is oftentimes too expensive to wait until crimes are committed: a proactive response is necessary, and effective crime

Farms are vulnerable to theft because of unique socio-demographic factors such as remoteness and distance between farms; often unchecked access to property; changing and unstable populations brought about partly by "sea-changers", "tree-changers" (i.e., both phrases referring to those seeking to escape the city for a more rural lifestyle) and hobby farmers; more relaxed attitudes to security; and offenders becoming more organised (Bunei, Rono and Chess 2013; Barclay and Donnermeyer 2011). There also exists in rural areas an ongoing (yet illconceived) urban notion of rural communities as a "rural idyll" free of crime (Jones 2012, 8; various contributors to Harkness, Harris and Baker, 2016 similarly expound upon this notion). Crime statistics, too, are skewed toward urban environments (see Carrington 2007, 28-30) where reporting rates are significantly higher than in rural spaces, with farmers more likely to deal with victimisation without the involvement of criminal justice agencies: indeed, many farmers consciously or sub-consciously self-regulate, subscribing to the view that, to adopt a colloquial Australian expression, "we kill our own snakes in the bush".

\section{Methodology}

The Victorian Farm Crime Research Project is an ongoing endeavour to examine types, extent and location of farm crime in Victoria (see Figure 1); consider attitudes of farmers and farming communities to criminal justice responses to farm crime; assess existing policing practices and analyse alternatives; and determine a suite of strategies for prevention and control of crime against farms and for improvement of service delivery by the criminal justice system in Victoria. An online survey of 51 Victorian farmers ${ }^{1}$ conducted between October 2013 and September 2014 consisted of both qualitative and quantitative questions. It adapted and added to questions posed by previous farm-crime surveys (such as Barclay, Donnermeyer, Doyle and Talary 2001; McCall 2003; Anderson and McCall 2005) to determine types and prevalence of thefts from farms in Victoria and added a series of attitude survey questions pertaining to perceptions of the criminal justice system and its responses. ${ }^{2}$ Interviews were conducted in November 2013 with seven Victoria Police members serving as Agricultural Liaison Officers $(\mathrm{AGLOs})^{3}$ to obtain qualitative data.

\section{Rural Criminological Thought}

Urban crime has long attracted the attention of scholars seeking explanations for offending behaviours (Mason 1996). ${ }^{4}$ The emergence of classical criminology in the latter half of the eighteenth century coincided with the industrial revolution where farm labourers and peasants 
migrated to the growing cities of Europe to live and to work in the factories. Common - indeed, almost universal - amongst each of the theoretical alignments which have emerged since is the intense focus on urbanism and offending in urban settings (Harris and Harkness 2016). Crime has been viewed predominantly as the domain of the urban working poor: the 'great unwashed'; the plebeians; the proletariat (see, for example, Braithwaite 1979; Graham and Clark 2001). By contrast, images of idyllic, crime-free areas beyond the cityscape persist, but scant (although emerging) academic consideration of the realities and variances of crime in rural and regional areas exists. This, combined with significant attention of metropolitan-based media outlets, elected representatives and instruments of the state to urban crime, has resulted in a paucity of public policy attention to crime in non-urbanised settings.

The neglect of rural criminological thought, Donnermeyer $(2007,3)$ avers, stems from the historical sociological focus on the transition of social organisation from the agrarian to the urban. Indeed, as Scott, Hogg, Barclay and Donnermeyer $(2007,1)$ observe, there exists a distinct lack of both normative and empirical research into notions of rural crime. This is particularly so in an Australian context. Neither does there exist sustained literature about the role of "place" on crime causation and effect, constructs of crime in non-urbanised settings, and criminal justice responses in rural areas, despite the rising significance of this as an issue (see, however, Harkness et al, 2016).

A number of works acknowledge the dearth of literature specifically regarding rural crime (for example, Scott et al, 2007, 1-2; Weisheit and Wells, 1996, 379). This is, however, gradually being addressed internationally (for example, Barclay and Donnermeyer, 2011 - Australia; Ceccato and Dolmen, 2013 - Sweden; Bunei et al, 2013 - Kenya), and theoretical assessments of crime beyond urban geographical boundaries are emerging (see DeKeseredy 2015; Donnermeyer 2007; 2012; DeKeseredy and Donnermeyer 2013; Donnermeyer, Scott and Barclay 2013; Donnermeyer and DeKeseredy 2014). Donnermeyer's (2016) Routledge International Handbook of Rural Criminology provides a welcome and significant advance in this field. Exploration of rural offending in a theoretical and empirical Australian context is offered by Barclay, Donnermeyer, Scott and Hogg (2007), Hogg and Carrington (2006) and Harkness et al (2016).

\section{Theoretical Crime Prevention Development}

Throughout the 1980s and 1990s, law and order solidified in the United States as a key electoral issue (Fuchs, 2015), particularly relating to the 'war on drugs' whereby drugs and crime also became increasingly racialised (Miller, 2008). Punitive responses to crime were demanded, and a dismantling of the welfare state (notably in the United States and the United Kingdom). 'Crime prevention', though, offered an alternative to punitive and retributive responses to crime, 


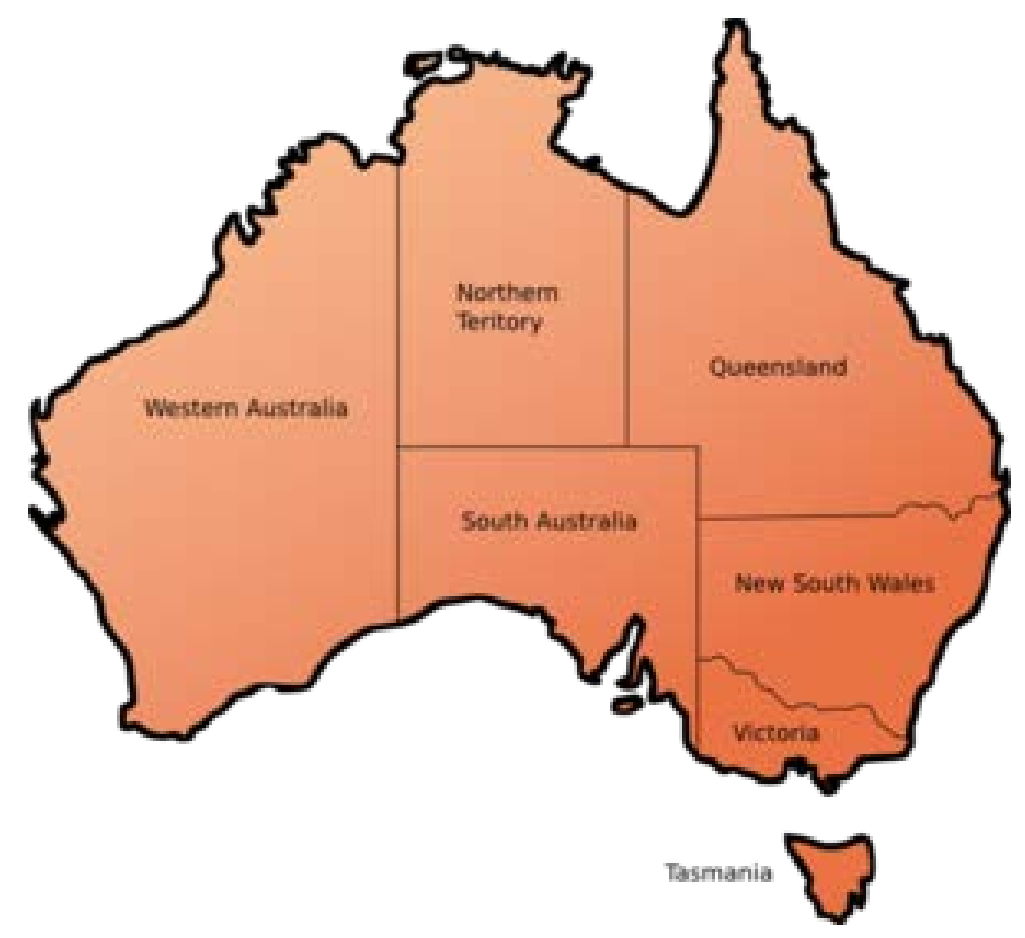

Figure 1: States/Territory of Australia

and was regarded as a more considered, apolitical, and economic response to crime. The role of community - being proactive rather than reactive - became important, alongside a recognition that the "police can’t do it alone” (Grant 2015, 3-5; see also Welsh and Farrington, 2012, 9-11).

Crime prevention is a broad concept which considers activities or initiatives intended to reduce the incidence and impact of offending: "any action or technique employed by individuals or private agencies aimed at reduction of damage caused by acts defined as criminal by the state" (Hughes 2001, 63). There exist three broad approaches to crime prevention: social; environmental; and situational. Social crime prevention focuses on addressing a person's likelihood of engaging in criminal conduct by dealing with underlying causal factors such as poverty, unemployment and lack of educational attainment (AIC, 2003) - the "root causes of crime” (Rosenbaum, Lurigo and Davis 1998, 201). Crime Prevention Through Environmental Design (CPTED) focuses on identifying, analysing and responding to the conditions which make an area physically unsafe. Initially focussed on planning rather than focussing on addressing specific crime areas or issues, early advocates included Newman (1972) with notions of "defensible space” in the "violent city" and Jacobs (1961) on urban regeneration and 'natural surveillance’ (Sutton, Cherney and White, 2008, 49; 60-64). 
The focus of this article, though, is on SCP initiatives and the reduction of opportunity for offending against farms. This is by no means a new phenomenon. Notions of "defensible space" (Newman 1972) and "opportunity and delinquency" (Cloward and Ohlin, 1960) provided the impetus for a groundswell of research and work aimed at considering criminal conduct from the perspective of the offender. Routine activity theory (Felson 2002; Clarke and Felson 1993) attempts to outline the circumstances necessary for criminal offending to occur, and posits that three factors converge for most (but not all) offending behaviour: presence of an offender (anyone with a motivation to offend), a target (either a physical structure or a person who can be victimised), and the absence of a "capable guardian" which would increase the risk of detection by human or security devices (Schneider 2010, 43; Sutton et al 2008, 59-60). Clarke (1997, 4), a pioneer in the formulation and advancement of contemporary SCP, provides a useful, succinct definition:

Situational prevention comprises opportunity-reducing measures that (1) are directed at highly specific forms of crime, (2) involve the management, design or manipulation of the immediate environment in as systematic and permanent way as possible, (3) make crime more difficult and risky, or less rewarding and excusable as judged by a wide range of offenders.

SCP is focussed on reducing opportunity for a potential offender to offend. As Sutton et al $(2008,51)$ note, SCP is aimed at understanding how "people perceive opportunities for crime" and how these opportunities might be removed at or least "less easily recognised". SCP is premised on the notion that a potential offender is presented with opportunities to commit a crime (Clarke 2005; Sutton et al p. 51) and makes a rational choice as to their behaviour (Clarke and Cornish 1986, Clarke and Felson,1993; Sutton et al 2008, 52). Essentially, SCP involves increasing the effort involved in crime (by making offending more difficult), increasing the risks of detection (real or perceived), and reducing the rewards for the offending. Sutton et al (2008, 54) warn, however, that simply transferring the specific techniques identified in the body of SCP research from one situation to another is perhaps unwise, as each were carefully developed and applied in certain specific circumstances. This is an appropriate warning to heed when evaluating SCP in farm environments: nevertheless, let us consider in broad terms farm crime prevention utilising these three broad categories.

\section{Increase the effort to offend}

A key element of SCP is to increase the effort to offend. Identifying key approaches in an urban context, Cornish and Clarke's (2003, 90) table of 25 situational techniques of situational prevention identifies target hardening, controlling access to facilities, screening exits, deflecting 
offenders and controlling tools and weapons as means of increasing effort. Specific techniques do not transfer easily to farm settings, though. Bunei et al (2013, p. 80) in their consideration of farm crime in Kenya note that:

... the nature of rural communities, coupled with transformations in their social, cultural and economic makeup, tends to increase the number of offenders and reduce guardianship, exposing farm property to greater risk.

Indeed, better roads and road networks, increased costs of machinery and farm inputs, greater reliance on seasonal workers, and expanding urbanisation "have increased the visibility, attractiveness, and accessibility of farm properties (Barclay and Donnermeyer 2011; Bunei et al 2013,. 81). Such economic, social and infrastructure advances have served to make offending easier: the challenge for farm communities and law enforcement, therefore, is to consider techniques to increase the effort to offend. Farms range in size and controlling access to and egress from many properties is extraordinarily difficult.

Barclay et al (2001) found that more than two-thirds of the New South Wales farmers surveyed had experienced some form of property crime over a two year study period, and this had increased to three-quarters based on a similar study in 2015 (Barclay 2016, 110). The first step in preventing farm crime, then, is acknowledging it occurs and, in assessing this, a question posed in the Victorian Farm Crime Survey (2014) asked respondents to evaluate the statement: $I$ worry about crime on my farm. Typical of many comments was the notion that whilst there needs to be awareness that farm crime is a possibility ("it happens occasionally... rarely, but it does happen"), there is not much that is achieved from worrying ("got to get on with life"). Nevertheless, farmers do implement a range of crime prevention measures in an effort to protect their property. Presented with a list of crime prevention measures, target hardening through locking sheds, buildings and vehicles was nominated as the most common action undertaken.

Sugden's $(1998,91)$ study of farm crime prevention in Rutland in the United Kingdom found a prevailing attitude amongst those surveyed that "crime on their farm 'was not a problem'”. This attitude can lead to an ambivalence towards or reluctance to invest too much time or money into target hardening, creating a significant barrier to law enforcement efforts. An AGLO (interview, 13 November 2013) reinforces this point, noting that ingrained habits are also an inhibitor to target hardening as “[o]ld habits die hard. People still don’t lock up sheds and they don't lock up houses and that's just an age-old problem”. Indeed, encouraging farmers to take extra care in hardening targets is, according to another AGLO (interview, 12 November 2013), "a very tough nut to crack". He advises that: 
They've done the same thing, the same practices for most of their lives. Most of them have been farming since they were little boys. They're now into their sixties. You just can’t change them. They leave keys in cars, sheds open...

In order to overcome a reticence to implement crime prevention initiatives, it is important for farmers to view effective prevention measures "as viable and achievable" (McCall and Homel, 2003, 2). If this is accepted, McCall and Homel (2003) observe, then:

... it is much more likely that serious efforts will be made with regard to development and implementation. If not, then energies and other resources are likely to be wasted on half-hearted and poorly implemented measures.

Attending to SCP precepts in a rural context is complicated by a rural mentality that "she'll be right" (that everything will be fine) and many opportunities are provided inadvertently for thefts to occur. Let us consider this by way of example. It is not uncommon on farms for a tank of fuel on a stand to be located in a paddock ready for refuelling machinery without the need to travel some distance back to a storage area and, in the context of fluctuating fuel prices, such thefts are common and relatively uncomplicated. Alternatively a trailer with a fuel tank on it might be towed to a location by tractor and left in situ. Many tractors are also left in paddocks overnight. Here, then, is an opportunity for fuel to be siphoned into large containers on the back of a utility vehicle or into jerry cans with relative ease and with little prospect of observance (interview, 14 November 2013). Whilst onerous and not always practicable, towing fuel trailers back to a locked shed each day would avoid the tank being drained. Complications for effective SCP arise, too, by requirements for signage indicating the presence of chemicals on a property (for appropriate public safety purposes) which has a corollary affect. As one surveyed farmer observed:

The biggest crime in our district is the theft of fuel. As farmers we all have bulk fuel tanks and by law we must display hazardous chemical signs on our driveway entrances stating what chemicals are stored on the premises. It doesn't matter if you have the tanks locked, a set of bolt cutters will soon get through the chain/lock.

Alongside unwillingness by some to change behaviours, there exist practical target hardening techniques to prevent thefts from farms, particularly the theft of firearms and machinery. Bull $(2007,162)$ notes, for instance, that target hardening against livestock theft is much more difficult owing to the highly organised nature of professional livestock thieves and the opportunistic theft from neighbours. Whilst cattle and sheep cannot be kept under lock and key, firearms can and by law must be. Victoria Police (interview, 11 November 2013a) note, 
nevertheless, a rise in the theft of firearms from farms by motivated individuals with organised criminal intent: long-barrelled weapons (an essential farming tool) are targeted and sawn-off for re-sale. State and territory firearm laws require that firearms be stored in anchored and locked receptacles, and it is an offence not to do so. However, Bricknell $(2012,32)$ suggests that "a critical factor in the prevention of firearm theft is owner compliance with prescribed firearm storage standards”. Indeed, an AGLO from Northern Victoria (interview, 13 November 2013) noted that "[u]nregistered firearms left in sheds is also an issue for us and, of course, farmers will be reluctant to admit that firearms have been stolen if they were unregistered”. A concern for police (interview, 14 November 2013), too, is that some farmers can at times be "pretty lackadaisical with their firearms":

They'll leave the firearm leaning up against the cabinet with all the ammunition or the key will be hanging on a hook on the side of the cabinet. So they have to be a bit more vigilant.

Ensuring that all firearms are registered and appropriately stored when not being used is crucial. Police have observed that hobby farmers who irregularly visit their properties might be required to store firearms at licensed gun shops rather than on a farm uninhabited for a lengthy time (interview, 11 November 2013a). Strengthened gun cabinets and keys ought to also be kept separate.

Barclay $(2016,117)$ observes that other than perhaps installation of security cameras, "no real change in security practices on farms” occurred between her 2001 and 2015 studies. This may well be attributed to issues of practicality - both time and effort - which can hinder willingness to adopt SCP practices. Perhaps for many urban dwellers, locking gates and sheds would appear intuitive. However, in many farm environments this is not possible as some sheds are large open workshops that cannot be locked. There exists, too, other hurdles, such as the time and effort required, as this account from a rural police member (interview, 12 November 2013) highlights:

But what they say to us, I've got like 150 gates on the farm and there's 30 sheds. Some of them need four or five locks. That's 30 times four. And they work out how many keys they need and everything else. And then there's the time. You've got to get out of the car, do this, do that, lock it up, go back right around the farm of a night and they say, Nah.

When it comes to farm machinery - and this is often a shock for urbanites accustomed to different keys and sophisticated anti-theft devices on modern cars - items such as tractors are 
keyed alike: one key fits all, unless modified after sale. Nevertheless, there are ways for farmers to be proactive in making offending more difficult. As one AGLO (interview, 12 November 2013) explains:

... we tell them to put two isolation switches in the machine, put one that's obvious, so they'll [thieves] muck about with it but you'll have one hidden somewhere else... we say to them, Have one outside under the bonnet or somewhere. They'll keep mucking about with this one but they won't know about the other one.

\section{Presence of capable guardianship to increase the risks}

In an urban context, the presence of both formal and informal surveillance - human and electronic - can provide the capable guardianship envisioned in Felson's (2006) explanation of routine activities theory. In a rural setting, however, this is much more difficult because, as Barclay (2007, 63-4; see also Barclay and Donnermeyer, 2011) suggests, ecological factors such as remoteness, terrain, visibility and accessibility, as well as small workforces and cost of technologies can make rural properties more vulnerable to victimisation. Nevertheless, the most effective crime prevention measure which respondents to the Victorian Farm Crime Survey (2014) identified was the importance of neighbours and being aware of unusual behaviour. Similarly, having farms appear to be occupied, having a permanent or random presence on the farm, and physically being present were nominated as important tactics. One farmer for instance, commentated that "even when we are away, we try not to make it obvious" and maintained that "being alert and not predictable, having people farm stay when we are away" were necessary measures. In this vein, another farmer noted that:

Vigilance is probably the most important. Staying alert. If you can identify a crime soon enough there is an increased chance of getting to the bottom of it. Neighbours watching is also probably very important but we all probably don't work closely enough with our neighbours.

A complicating factor in ensuring human guardianship on farms, an AGLO from Victoria's western district (interview, 12 November 2013) remarks, is that farmers are often absent and, indeed, some choose to live away from their farms and commute to it each day:

$\ldots$ and a lot of them - in some of the areas up here, there's a bit of a move where the older farmers are moving into [town] yet still farming on the land that might be 20 or 30 [kilometres] out. So they are coming in here for the lifestyle, so that they can be in town rather than make all the trips in, yet still actively working the farms. 
International Journal of Rural Criminology, Volume 3, Issue 2 (June), 2017

Not only does this provide offending opportunities at night, with no human presence to provide capable guardianship, but offending opportunities are enhanced with poor target hardening practices:

But then [they leave] everything unlocked on the farm like they have done for the past sixty years. So you can see, that's a bit of a problem.

However, the landscape, the geography of rural landscapes, can be conducive to guardianship. Notwithstanding the remoteness of some farms, offenders in rural areas are more likely to be noticed than in the city. Commenting on this, an AGLO (interview, 13 November 2013) from Victoria's north observed that there is:

[n]othing more noticeable than a bloke that the farmer doesn't know driving down the back lane or even down the main road. They'll know whose car it is - they all tend to know that so they tend to stick out a bit more so you get more report of, $I$ saw a suspect car down the back lane there. But in the city of course, people don't look twice.

Anderson and McCall $(2005,15)$ note that farms with no capable guardian present (for instance being unattended or being greater than 1000 hectares in size) experience a high level of victimisation. However, they also found that the presence of farmers, family members or employees on a property by no means mitigates against the incidence of theft from farms: farms with greater than 10 employees were also likely to experience higher rates of victimisation. Without doubt, some people invited on to a farm to work, as employees or contractors, may indeed have criminal intent. Labour-force changes have certainly impacted on community composition and an increased presence of non-residents in farming communities. The account of an AGLO in Victoria's Wimmera district in the state’s west, a large grain growing region (interview, 12 November 2013), is pertinent:

... in the old days, [farmers] used to harvest themselves. Now they get contractors in... They come into the area and they bring with them their own truck drivers and everything else... from the Monday to Friday, they'd be at the direction of the farmers. They would be taking certain loads of grain straight to a silo to be sold. And other loads of grain would be going to the silos on their farm for holding. On the Friday afternoon, because the truckies have had all week to work out who's who and what's going on, one of them was slipping into a farm and taking grain out of a silo on the farm, taking that grain interstate and selling it to his local silo up north to get the cash for a truck load of grain. 
It is also noteworthy that, apart from some transient organised crime, police believe that offenders possess a degree of agricultural knowledge (interview, 12 November 2013):

... we've found that whenever we've solved rural crime, like the wool thefts and the thefts of bailers and all that sort of thing, the theft of grain, it's always somebody that's in that - the agricultural work. It's not a city slicker that's come here... it's either the truck drivers, the rouseabout, a farm hand.

To enhance capable guardianship by humans, additional support from government for Neighbourhood Watch styled groups in local communities might be a practical initiative, too. Rural Eye Watch in New South Wales is aimed at reducing preventable crime by increasing knowledge sharing, improving security in rural areas (particularly on farms), and encouraging citizens to be more diligent in reporting to police. In so doing, enriched police-community relationships, which enable police to better respond to crime and to develop a sense of community cooperation and responsibility, is a feasible outcome. The Farmwatch scheme in Cumbria in the United Kingdom is another potentially advantageous model for farming communities to consider. Such schemes, however, are less effective where properties are particularly geographically isolated and where the scheme is not fully embraced by the local community (McCall and Homel, 2003, 4) and there is reduced potential for capable guardianship.

Unlike in urban environments, it is neither financially viable nor logistically possible for farmers to simply install improved boundary fencing, personal identification number entry or other techniques to control access to properties. In an Australian context, farms are often immense in size; farm sheds and equipment are often located some distance from farm houses (or at least out of sight); and livestock are located in paddocks without active human surveillance. In this respect, tried and tested SCP techniques employed in urban settings are ineffective in rural ones. Some farmers, though, are aware of the value of having capable guardianship in electronic form on the farm: one farmer noted that having security systems with signage advising of the presence of recording devices will act as a deterrence "as most people think twice about stealing when they know they are being watched". This is, indeed, indicative of 'panopticonism', a concept borne by Jeremy Bentham's renowned Panopticon, an architectural prison design whereby the few watch the many leading to deterrence of poor behaviour by prisoners, which was reimagined by Michel Foucault and which has led to broader notions of surveillance studies external to prison environments (Brunon-Ernst and Tuesseau 2012).

The declining cost of sensor lights and motion activated cameras has resulted in increased installation across Australia. Victoria Police AGLOs actively promote the installation and use of motion activated cameras that "can last for up to a week", believing that "[i]f they [farmers] put them in strategic places, although it doesn't stop the thieving, it will certainly help get a little bit 
of evidence to try and catch the people” (interview, 12 November 2013). Several farmers recognised the value of such devices, noting that video surveillance is important in capturing, at least, some form of information. Perhaps then, such mechanisms have use not simply in panopticonistic crime prevention but in the policing, prosecuting and punishing of crime. In and of itself, this could help in demonstrating the criminal justice system is capable of responding to farm crime. Despite reduced costs, there persists a perception that electronic guardianship is expensive: with unlimited resources, though, an array of crime prevention measures could be implemented. Asked to nominate their favoured response, farmers overwhelmingly indicated (unprompted) that they would install video surveillance and "spy cameras" on entry points, sheds and gates. One farmer gave this question extensive consideration, noting that:

I would have perimeter cameras set up on the boundary, cameras at set intervals along the laneways, cameras in the hay shed, calving shed, feedpad area and calf sheds, key card only gates on all entrances, all cameras would be monitored by a security company.

Another farmer indicated that video surveillance, sensor lights and padlocks on all gates would be appropriate, although padlocking all gates would be impractical because of the number of keys needed for employees and contractors. The cost of deploying electronic security systems across a large farm is an inhibiting factor for some farmers, and so perhaps a consideration for government to lessen farm victimisation might be for a subsidy scheme to assist farmers in installation of devices, and for incentives to be offered by, say, insurers in the form of lower premiums, for farmers who implement crime prevention measures.

\section{Reporting crime to increase risk of being caught}

Reporting crime increases the risk for offenders to be detected and, as one AGLO (interview, 14 November 2013) noted, farmers not reporting incidents of theft "is an issue because if we don't know about it, we can't do anything about it. We're not aware of the emerging trends and things like that with the crime”. Information is crucial for police, too, to assist in preventing repeat victimisation (interview, 14 November 2013):

... the biggest thing we rely on to get the job done is information. And that comes from everywhere. Farmers, police and so on, so it's all about education I suppose and getting them to have faith in us... if they don't want to dob in their neighbour they think their neighbour's knocked the sheep off - they're still a thief. And farming communities tend to want to deal with things themselves and then they end up being targets. If somebody knocks off a hundred sheep one time and they get away with it, next time they will come and knock off two hundred. Cut their fences 
and go in and get five hundred next time. So if they don't report it to us, they're more likely to be a target.

McCall and Homel $(2003,3)$ note that non-reporting of crime is “[p]erhaps the most important issue constraining the implementation of effective crime prevention measures on farms”. Barclay $(2016,111)$, drawing upon her own research in New South Wales and Queensland and from studies in South Africa and the United Kingdom, notes that notwithstanding the financial and personal losses created by farm crime, few offences are reported to police. Reasons for non-reporting vary. Barclay $(2007,65)$, for instance, found that respondents to her 2001 study cited difficulty in proving the crime (56\%), difficulty in determining if a crime had occurred (53\%) and that too much time had passed (52\%) were the principal reasons for non-reporting.

Other reasons are more varied. For instance, one farmer (Victorian Farm Crime Survey 2014) treated the loss of fencing from his farm as a joke: "Who would steal treated pine rails all bolted in position to keep the cattle yard [fence] wires tight!” Concern about police involvement was also cited by another farmer:

Fuel was drained from tank of truck left in paddock at harvest time. Last thing you want is cops sniffing around at harvest time checking overloading, truck roadworthies etc when you're in a hurry as it is the busiest time of year. Just sucked it up and got on with it, they wouldn't have been able to do anything anyway.

Failure to report also occurs when losses occur over a period of time or when there is a lag in noticing items missing. This is particularly so with non-reporting of livestock theft, when farmers are uncertain whether stock was definitely stolen. Sheep, for instance, might be mustered about three or four times a year (to shear, drench or count stock) and the loss of a small number might go unnoticed for several months as an AGLO (interview, 12 November 2013) from Western Victoria explains:

It could be six months before [farmers] realise there is stock missing. Given the fact of the remoteness of some areas we deal with in this division, they might not check their stock for one or two months and it could be six months before they realise there's 20 or 30 head missing.

Wild dog or fox attacks cannot be ruled out either, although normally in such cases carcasses, blood, fur or damaged fences might be evident. Onus of proof, difficulty in obtaining evidence and a resignation that police might never recover the stolen stock are also reasons for non-reporting (Victorian Farm Crime Survey 2014). One AGLO’s (interview, 14 November 2013) observations are illustrative of this: 
It's difficult to tell sometimes because a lot of the time they'll do a head count when they put the sheep in, when the buy them and put them in the paddock, and then when they go to do a muster for lamb marking or for sale or something like that, it might be three months later, they'll go around and count the sheep and realize they are two hundred short. Any evidence of tyre tracks or offenders that may have left there is gone. It's difficult.

Often, the offender may be a farmer or otherwise known to the victim. Neighbouring farmers or other locals are sometimes considered the likely perpetrators of stock theft: "If one or two head taken (a beef heifer for instance) then possibly [it could be found in] a neighbour's freezer" (interview, 12 November 2013). Whilst livestock might be taken opportunistically to sell, a farmer (Victorian Farm Crime Survey 2014) observed that it is not necessarily criminals with motivation for profit who steal livestock:

The biggest criminal problem in our locality is due to livestock being stolen and killed on site or elsewhere for human consumption. Why? Poverty of community maybe but as my husband just said "there is a preponderance of dickheads around". They have four wheel drives, mates, time, guns, and enough skills to achieve it.

For an AGLO in Victoria’s western districts (interview, 12 November 2013), a prevailing attitude of "we've got to live next door to them" abets non-reporting of livestock theft:

... even the ones who know that their own neighbours have stolen their sheep, they still don't do anything about it... The other strange thing I noticed with it is that if we find the tractor and we tell them that their neighbour stole it, they are happy to have their neighbour charged. However, if we find the stock on their neighbour's property, they don't want their neighbour charged, so it's a real funny situation.

Fears of revenge by offenders for reporting is a significant barrier. Two farmers (Victorian Farm Crime Survey 2014), for example, noted that:

Revenge and injury to livestock has been threatened. The police protect the offenders by saying nothing can be done.

Revenge is a very serious problem. Farmers are very vulnerable to hate crime and social pressure.

There is, nevertheless, a strong mood and desire for 'justice' - an amorphous term, certainly - to prevail. Speaking to this, a number of farmers highlighted that farms are businesses and that stealing affects income generation. One farmer noted that: 
Because victims need justice, offenders need to be prosecuted and stolen livestock and machinery needs to be recovered and returned and if not victims must be compensated. When a theft occurs on a farm, the livelihood of the farmer can be severely affected. Can take many years to recover financially from a theft.

An attitude prevails, too, that the courts are too lenient on people who steal from farms, that the conviction rate is too low and that the criminal justice system is too "soft" on farm crime offenders. As one farmer remarked, "there are no repercussions for those who break the law only for those they steal from” (Victorian Farm Crime Survey 2014). Another farmer observed that:

[P]eople don't have a strong understanding that a farm is a business and that it is difficult to be profitable. Offenders and the courts quite possibly take it all lightly.

When asked to consider the most recent occasion when an instance of crime on their farm proceeded to court, respondents indicated dissatisfaction with the response of the courts, such as:

rubbish sentence

the fines should have been much higher

thieves let off with cautions despite having been caught thieving in the neighbourhood previously

It was noted earlier that there is a reluctance to report farm crime because of the difficulty in knowing the crime has occurred ("[m]ost of the time we don't know the theft has happened until well after the fact”), identifying offenders (“you have to catch them first!”), and producing evidence to support suspicions of who might be offending. This leads, of course, to difficulties in prosecuting offenders who have been identified. Some farmers believe this to be a failing of the criminal justice system. One farmer's observation in particular is worth recording here:

The law is too archaic and not nimble enough to respond. We had to go to VCAT [the Victorian Civil and Administrative Tribunal] and have our issue sorted. It was tremendously stressful on our family and the police couldn't do anything helpful.

The loss of time in formally responding to crime is also a significant issue. Many farms are small businesses with few employees in the business, and time spent away from the farm can present a significant cost. The high cost of legal advice or representation was also identified by one farmer as a factor dissuading reporting. 
Other farmers drew attention to what they believed to be an insufficient local police presence and ineffective policing responses to reported crime, and scepticism about the police themselves was nominated as a reason not to report: "Police have conflicts of interest and protect people known to them in the community”, one farmer observed. There exists here, too, a high degree of scepticism. Three farmer's perspectives highlight this: “cops don't do nothing, would like to know why”; "nothing is being done, but don’t expect it to be either”; and magistrates let everyone off with a caution and no consequences (Victorian Farm Crime Survey 2014). These anecdotal perspectives mirror Barclay’s $(2007,65) 2001$ survey findings where respondents nominated “waste of time reporting - police can’t do much” (43\%) and "police have no knowledge or understanding about farming” (23\%) as reasons not to report crime.

Several respondents noted that, whilst they see police performing traffic roles in their communities, they see little outcomes in terms of theft recovery and prosecution; and that "farm crime is probably the least of their worries”. Some speculated that drugs, family violence and "urban issues" occupy the bulk of police time. An AGLO from central Victoria (interview, 14 November 2013) noted that police need to accept a degree of responsibility for non-reporting:

But I think that's partially our fault as well. They've [farmers] got to have confidence in us to do our job: like if they get ten sheep knocked off, they think, $A h$, I won't bother reporting that to the police. It's not worth it because there's not going to be a result. Whereas we'd like to be able to say to them, Come in and report it and we'll find your ten sheep for you. And we'd get the offender and charge him. You can't always do that so we've got to have the capacity to do that.

Qualitative interviews conducted by Anderson and McCall for the National Farm Crime Survey 2002-3 (2005, 32-4) regarding farmers' perceptions of police saw five key themes emerge: (i) that police lack necessary resources to tackle farm crime; (ii) suspicion or fault was being directed at farmers; (iii) that police do not care about farm crime; (iv) that police lack industry knowledge; and (v) farmers are suspicious about some police. There is perhaps, then, a necessity for police to bolster efforts to enhance stronger police-community partnerships within a community policing framework and to aid in the building of social-capital - as critical in rural settings as it is in urbanised ones (Harkness 2015).

\section{Reduce the Rewards - Property Identification}

Marking property is aimed at reducing "the perceived rewards associated with a crime by making targets harder to sell, deterring offenders from targeting marked property” (Morgan, Boxall, Lindeman and Anderson, 2011, 61). Separovic and Brooks (2014) note that there is scant 
evidence to suggest that property marking is an effective technique to prevent thefts (other than for vehicles, perhaps), but that marking can assist in the return of stolen property to rightful owners (p. 34):

The effective use of property marking does not directly affect the predisposition of an individual to display deviant behaviour. However, it may indirectly affect the willingness of an individual to steal an item due to the risk of not being able to sell the item which is marked. Property marking may also act as a passive extension of guardianship, as the permanent marking represents ownership which may increase the risk to the offender if caught in possession, or attempting to resell the property.

Survey respondents who indicated that they had experienced livestock theft reported that it was often only a few head of cattle, sheep or goats stolen rather than large numbers at any time. This point is supported by AGLOs, too (interview, 12 November 2013; interview, 14 November 2013). Survey responses indicated that recovery of livestock is highly unlikely and victims of livestock theft were unlikely to have their animals insured in any way, or if they did then for fire but not theft. The National Livestock Identification System (NLIS) was introduced in Australia in 1999 for tracing cattle and requires radio frequency identification devices containing microchips encoded with unique numbers to be applied to livestock to trace them from birth to slaughter. A database of stock movements is maintained to allow rapid tracing of stock and owners of various livestock species are required to obtain to have an eight character Property Identification Code (NLIS 2015; Harkness 2016, 99-100).

There exists a problem with identification of sheep, however. Whilst cattle have electronic ear tags, owners of sheep are only required to affix plastic tags to their livestock which are easily removed, making stock identification almost impossible. One AGLO (interview, 12 November 2013) explains that:

The biggest thing that we find with sheep or any stolen property if you take away that it's an animal or livestock, is identifying property as being stolen. If the sheep don't have the right tag on them, we can't identify them. They are written off straight away. Cattle get stolen less because they have electronic ear tags. They still do get stolen and replaced but sheep don't have the electronic ear tags. Farmers are reluctant to get them because it's a cost. So subsidizing the cost of ear tags can help I guess.

Victoria Police have identified industry complacency, inadequate legislation pertaining to the NLIS, limited government enforcement, and lack of mandatory electronic identification of 
of sheep (flock recording is currently paper-based) as limiting factors in policing of livestock theft. Dishonest stock agents and poor transport legislation are also inhibiting factors (Field, 2013, 1). Tracing livestock has improved with the requirement for National Vendor Declaration forms for any external movement of stock but poor regulation, ease of abusing the system (offenders can remove and replace tags and sell stock with falsified paperwork ( and low prosecution rates are other significant issues confronting police (Field 2013, 4). Nevertheless, whilst livestock theft is an issue, AGLOs around Victoria reported that property theft is a more significant issue: "although they kick up a big stink about livestock, it is very, very small compared to the rest of the rural theft. It's the property that is the biggest thing” (interview, 12 November 2013). This is an important point to consider: perceptions of crime problems (as opposed to realities) can be significant in shaping and governing responses to, and indeed preventing, crime.

Survey respondents indicated that machinery stolen from farms included power tools, rotary hoes and tractors. In most cases, the machinery was not recovered; almost all victims of machinery theft indicated that the items were not marked in any particular identifiable way; and for more than half the items were not at all insured. AGLOs in Western Victoria indicated that the driver in rural crime in that area is farming property, including implements, tractors, trailers and fuel. Diesel fuel, in particular is a significant issue, as is theft of grain from silos and wool from woolsheds (interview, 12 November 2013). Items can be quite difficult to identify. Wheat headers, for instance, are almost all identical, one AGLO observes (interview, 14 November 2013), unless a farmer has modified it or made identifiable repairs:

Sometimes if the farmer has had it for some time, something might have broken on it. He might have had to weld this piece of steel on it to repair it, so we can identify it through that way but it certainly doesn’t have serial numbers which is an issue.

\section{Conclusion}

Farms in Victoria, Australia are targeted by well-organised, well-equipped and highlyskilled farm thieves with industry knowledge and ready markets to dispose of stolen items; and by opportunistic thieves. Both present a significant issue for farming communities and police alike. This, combined with a persistent degree of complacency from farmers, an oftentimes reluctance to report, impracticality of many target hardening measures, and difficulties in ensuring capable guardianship, adds to the degree of complexity in combatting the social and economic effects of farm crime.

Whilst there is a growing body of scholarly work on farm crime, much more is needed to determine the extent of and best responses to farmer victimisation. This article has focussed on just one jurisdiction, but the observations from police and farmers presented here are 
instructive more broadly in considerations of specific crime prevention tactics and techniques. The Victorian Farm Crime Project will continue apace and, overtime, intends to accept the challenge offered by Barclay and Donnermeyer $(2011,16)$ to test the effectiveness of a range of specific technologies and practices in agricultural settings.

\section{Endnotes}

${ }^{1}$ The sample size is acknowledged as small, but responses (particularly to attitude questions) are instructive.

${ }^{2}$ This survey was composed of 88 questions and constructed in four parts: Part A - information about a respondent's farm; Part B - their experiences of different types of farm crime; Part C other types of crime; and Part D - perceptions of and responses by the criminal justice system. A link to the survey was emailed to members of the Victorian Farmers Federation (VFF) and was also publicised on several regional radio stations, in press reports, and on Twitter. Postcodes were sought from participants to ensure that they lived within the state of Victoria. Respondents were asked a series of questions about experiences of thefts and other forms of crime. The survey was entirely voluntary and anonymous, and respondents were able to skip questions not pertinent to them or which they were unwilling or unable to answer.

${ }^{3}$ Approximately 48 AGLOs, comprised mostly of general duty detectives and some uniformed officers are located strategically around the State. AGLOs and are coordinated by the Head of Practice for the Livestock and Farm Crime Specialist Group. Police members are selected to be AGLOs based on their "knowledge, skills and expertise to deal with livestock theft and farmrelated crime" (Victoria Police 2012, 45). A central information hub provides AGLOs and other police members with access to information. Senior officers are advised by a Strategic Advisory Group which includes representatives from the Victorian Farmers Federation (VFF), Department of Primary Industries and the Municipal Association of Victoria (Victoria Police 2012,45).

${ }^{4}$ For detailed exploration of the transition of criminological thought over time, see for example, Vold, Bernard and Snipes 2002; Mason 1996; White, Haines and Asquith 2012. 


\section{References}

ABS (Australian Bureau of Statistics). (2012). Australian social trends, Cat No 4102.0. Canberra: Australian Bureau of Statistics.

Anderson, K. M. and McCall, M. (2005). Farm crime in Australia. Canberra: Australian Institute of Criminology.

AIC (Australian Institute of Criminology). (2003). Approaches to understanding crime prevention. AICrime reduction matters no. 1, May. Canberra: Australian Institute of Criminology.

Barclay, E. (2016). Farm victimisation: The quintessential rural crime. In J. F. Donnermeyer (Ed.). The Routledge international handbook of rural criminology. London: Routledge.

Barclay, E. and Donnermeyer, J. F. (2011). Crime and security on agricultural operations. Security Journal, 24(1), 1-18, https://doi.org/10.1057/sj.2008.23

Barclay, E. and Donnermeyer, J. F. (2007). Farm victimisation: The quintessential rural crime. In E. Barclay, J. F. Donnermeyer, J. Scott and R. Hogg (Eds). Crime in rural Australia (pp. 57-69). Sydney: The Federation Press.

Barclay, E., Donnermeyer, J. F., Doyle, B. P. and Talary, D. (2001). Property crime victimisation and crime prevention on farms. University of New England, Armidale: The Institute for Rural Futures.

Barclay, E., Donnermeyer, J. F., Scott, J. and Hogg, R. (Eds). (2007). Crime in rural Australia. Sydney: The Federation Press.

Braithwaite. J. (1979). Inequality, crime and public policy. London: Routledge and Kegan Paul.

Bricknell, S. (2012). Firearm trafficking and serious and organised crime gangs. Canberra: Australian Institute of Criminology.

Brunon-Ernst, A. and Tusseau, G. (2012). Epilogue: The panopticon as a contemporary icon? In A. Brunon-Ernst (Ed.). Beyond Foucault: New perspectives on Bentham's panopticon. Farnham, Surrey UK: Ashgate.

Bunei, E. K., Rono, J. K. and Chessa, S. R. (2013). Factors influencing farm crime in Kenya: Opinions and experiences of farmers. International Journal of Rural Criminology, 2(1), 75-100. 
Bull, M. (2007). Crime prevention and rural communities. In E. Barclay, J. F. Donnermeyer, J. Scott and R. Hogg (Eds). Crime in rural Australia (pp. 72-85). Sydney: The Federation Press.

Carcach, C. (2000). Regional development and crime. Trends and Issues in Crime and Criminal Justice, No. 160. Canberra: Australian Institute of Criminology.

Carcach, C. (2002). Farm victimisation in Australia. Trends and Issues in Crime and Criminal Justice, No. 235. Canberra: Australian Institute of Criminology.

Carrington, K. (2007). Crime in rural and regional areas. In E. Barclay, J. F. Donnermeyer, J. Scott and R. Hogg (Eds). Crime in rural Australia (pp. 27-43) Sydney: The Federation Press.

Ceccato, V. and Dolmen, L. (2013). Crime prevention in rural Sweden. European Journal of Criminology, 10(1), 89-112, https://doi.org/10.1177/1477370812457763

Clarke, R. V. and Cornish, D. B. (Eds). (1986). The reasoning criminal: Rational choice perspectives on offending. New York: Springer Verlag.

Clarke, R. V. and Felson, M. (1993). Routine activity and rational choice: Advances in criminological theory. New Brunswick NJ: Transaction.

Clarke, R. V. (1997). Situational crime prevention: Successful case studies. $2^{\text {nd }}$ edn. New York: Harrow and Heston

Clarke, R. V. (2005). Seven misconceptions of situational crime prevention. In N. Tilley (Ed.). Handbook of crime prevention and community safety. Cullompton, Devon UK: Willan.

Cloward, R. A. and Ohlin, L. (1960). Delinquency and opportunity: A theory of delinquent gangs. New York: Free Press.

Cornish, D. B. and Clarke, R. V. (2003). Opportunities, precipitators and criminal decisions: A reply to Wortley's critique of situational crime prevention. Crime Prevention Studies, 16, 41-96.

DeKeseredy, W. S. (2015). New directions in feminist understandings of rural crime. Journal of Rural Studies, 39, 180-187, https://doi.org/10.1016/j.jrurstud.2014.11.002

DeKeseredy, W. S. and Donnermeyer, J. F. (2013). Thinking critically about rural crime: Toward the development of a new left realist perspective. In S. Winlow and R. Atkinson (Eds). New directions in crime and deviancy (pp. 206-222). New York: Routledge. 
International Journal of Rural Criminology, Volume 3, Issue 2 (June), 2017

Donnermeyer J. F. (2007). Rural crime: Roots and restoration, International Journal of Rural Crime, 1, 2-20.

Donnermeyer, J. F and DeKeseredy, W. S. (2014). Rural criminology, London: Routledge.

Donnermeyer, J. F. (2012). Rural crime and critical criminology, In W. S. DeKeseredy and M. Dragiewicz (Eds), Routledge handbook of critical criminology (pp. 290-302). London: Routledge.

Donnermeyer, J. F. (Ed.). (2016). The Routledge international handbook of rural criminology. London: Routledge.

Donnermeyer, J. F., Scott, J. and Barclay, E. (2013). How rural criminology informs critical thinking in criminology. International Journal for Crime, Justice and Social Democracy, 2(3), 69-91, https://doi.org/10.5204/ijcjsd.v2i3.122

Felson, M. (2002). Crime and everyday life, $3^{\text {rd }}$ edn. Thousand Oaks, CA: Pine Forge Press.

Felson, M. (2006). Crime and nature. Thousand Oaks, CA: Sage.

Field, E. (2013). System failure. Weekly Times, Albury NSW: 1;4. Published on 24 ${ }^{\text {th }}$ July, 2013.

Flora, C. J. and Flora, J. L. (2008). Rural communities: Legacy and change, $3^{\text {rd }}$ edn. Boulder CO: Westview Press.

Fuchs, E. (2015). It's incredible how much safer America has become cince the 1980s. Business Insider. Published on $28^{\text {th }}$ January, 2015. Retrieved 29/11/2015 from http://www.businessinsider.com.au/fbi-crime-report-shows-america-is-still-getting-safer2015-1

George, A. and Harris, B. (2014). Landscapes of violence: Women surviving family violence in regional and rural Victoria. Geelong Vic: Centre for Rural and Regional Law and Justice, Deakin University.

Graham, P. and Clark, J. (2001). Dangerous places: Crime and the city. In J. Muncie and E. McLaughlin (Eds). The problem of crime, $2^{\text {nd }}$ edn. Thousand Oaks CA: Sage.

Grant, H. (2015). Social crime prevention in the developing world: Exploring the role of police in crime prevention. New York: Springer, https://doi.org/10.1007/978-3-319-13027-9

Harkness, A., Harris, B. and Baker, D. (Eds). (2016). Locating crime in context and place: Perspectives on regional, rural and remote Australia, Sydney: The Federation Press. 
Harkness, A. (2015). Police as builders of social capital with farmers: Addressing property theft from farms in Victoria, Australia. Crime, justice and social democracy: Proceedings of the $3^{\text {rd }}$ international conference 2015, Volume 1. Brisbane: Queensland University of Technology.

Harris, B. and Harkness, A. (2016). Introduction: Locating regional, rural and remote crime in theoretical and contemporary context. In A. Harkness, B. Harris and D. Baker (Eds). Locating crime in context and place: Perspectives on regional, rural and remote Australia. Sydney: The Federation Press.

Hogg, R. and Carrington, K. (2006). Policing the rural crisis. Sydney: The Federation Press.

Hollis, M. E., Felson, M. and Welsh, B. C. (2013). The capable guardian in routine activities theory: A theoretical and conceptual reappraisal. Crime Prevention and Community Safety 15, 65-79, https://doi.org/10.1057/cpcs.2012.14

Hughes, G. (2001). Crime prevention. In E. McLauchlan and J. Muncie (Eds). The Sage dictionary of criminology. London: Sage Publications.

Jacobs, J. (1961). The death and life of great American cities. New York: Sage Random House.

Jones, J. (2012). Looking beyond the 'rural idyll': Some recent trends in rural crime. Criminal Justice Matters, 89(1), 8-9, https://doi.org/10.1080/09627251.2012.721964

Mason, B. (1996). From shamans to shaming: A history of criminological thought. In K. M. Hazlehurst (Ed.). Crime and justice: An Australian textbook in criminology. North Ryde, NSW: LBC Information Services.

McCall, M. (2003). Results from the 2001-02 National Farm Crime Survey. Trends and Issues in Crime and Criminal Justice, No. 266. Canberra: Australian Institute of Criminology.

McCall, M. and Homel, P. (2003). Preventing crime on Australian farms: Issues, current initiatives and future directions. Trends and Issues in Crime and Criminal Justice, No. 268. Canberra: Australian Institute of Criminology.

Miller, L. L. (2008). The perils of federalism: Race, poverty, and the politics of crime control. New York: Oxford University Press, https://doi.org/10.1093/acprof:oso/9780195331684.001.0001

Morgan, A., Boxall, H., Lindeman, K. and Anderson, J. 2012, Effective crime prevention strategies for implementation by local government, Research and Public Policy Series, No. 120. Canberra: Australian Institute of Criminology. 
International Journal of Rural Criminology, Volume 3, Issue 2 (June), 2017

Newman, O. (1972). Defensible space: People and design in the violent city. London: Architectural Press.

NFF (National Farmers’ Federation). (2014). Annual Review 2013-14. Canberra: National Farmers' Federation.

NLIS (National Livestock Identification System). (2015), National Livestock Identification System. Retrieved 14/12/15 from https://www.nlis.com.au/NLIS-Information/

Rosenbaum, D. P., Lurigio, A. J. and Davis, R. C. (1998). The prevention of crime: Social and situational strategies. Belmont CA: Wadsworth Publishing.

Schneider, S. (2010). Crime prevention: Theory and practice. Boca Raton, FL: CRC Press.

Scott, J., Hogg, R., Barclay, E. and Donnermeyer, J. (2007). Introduction. In E. Barclay, J. F. Donnermeyer, J. Scott and R. Hogg, (Eds). Crime in rural Australia (pp. 1-14). Sydney: The Federation Press.

Separovic, C. and Brooks, D. J. (2014). Efficacy of property marking: Police identification of stolen property, Proceedings of the $7^{\text {th }}$ Australian Security and Intelligence Conference. Perth, Western Australia: Edith Cowan University.

Sudgen, G. (1998). In defence of farms: An agrarian crime prevention audit in Rutland. In M. Gill (Ed.). Crime at work (Volume 2): Increasing the risk for offenders. London: Palgrave McMillan.

Sutton, A., Cherney, A. and White, R. (2014). Crime prevention: Principles, perspectives and practices, $2^{\text {nd }}$ edn. Port Melbourne, Vic.: Cambridge.

United Nations (2004). The rule of law and transitional justice in conflict and post-conflict societies: Report of the Secretary-General. Cited in Homel, P. (2009). Improving crime prevention knowledge and practice. Trends and Issues in Crime and Criminal Justice, No. 385. Canberra: Australian Institute of Criminology.

Victoria Police (2012). Annual Report 2011-12. Melbourne: Victoria Police. Retrieved 3/9/15 from www.police.vic.gov.au/annualreports/ebooks/2012/files/assets/basichtml/page45.html

Vold, G., Bernard, T. J. and Snipes, J. B. (2002). Theoretical criminology. New York: Oxford University Press. 
Weisheit, R. A. and Wells, L. E. (1996). Rural crime and justice: Implications for theory and research. Crime and Delinquency, 42(3), 379-397, https://doi.org/10.1177/0011128796042003003

Welsh, B. C. and Farrington, D. P. (2012). Crime prevention and public policy. In B. C. Welsh and D. P. Farrington (Eds). The Oxford handbook of crime prevention. Oxford: Oxford University Press, https://doi.org/10.1093/oxfordhb/9780195398823.013.0001

White, R., Haines, F. and Asquith, N. (2012). Crime and criminology, $5^{\text {th }}$ edn. Melbourne: Oxford University Press. 